\title{
EXPERIMENTAL STUDY OF INTERACTION SHALE-FLUID THROUGH IMMERSION TESTS
}

\author{
Claudio Rabe* \\ rabe@ civ.puc-rio.br \\ Sérgio Augusto Barreto da \\ Fontoura* \\ fontoura@civ.puc-rio.br \\ Franklin dos Santos Antunes* \\ *Grupo de Tecnologia e Engenharia de \\ Petróleo, Departament of Civil \\ Enginnering, PUC-Rio \\ Rua Marquês de São Vicente, 225 - \\ Edifício Padre Leonel Franca, $6^{\circ}$ Andar - \\ Gávea - Rio de Janeiro RJ - Brazil - CEP \\ 22451-900 - Tel/Fax: +55 213114.1458 .
}

\begin{abstract}
The present work has as objective the study of the behavior of preserved shale samples when immersed in aqueous solutions. The obtained results show that the solutions presented high variations of $\mathrm{pH}$, salinity and electric conductivity, what indicates ionic migration of salts from the rock to the fluid, and small variations of Redox potential. Chemical analysis indicate strong migrations of ions from the rock to the fluid. It can also be observed that the solutions become cloudy, denser and more viscous. Besides, the samples suffer elevations of its water content, small variation of its cation exchange capacity and chemical composition, loss of solid material from superficial disintegration and the development of fractures in the cores. This work contributes to the understanding of the shale behavior in presence of drilling fluid water base.
\end{abstract}

Key words: interaction shale-fluid, immersion tests, physical-chemical.

\section{INTRODUCTION}

During the drilling of oil wells, the fluid interacts with the shales layers in the walls of the well, with the cuttings and at the contact drill bit-rock. The physical-chemical interaction between shales and the drilling fluids is still a well engineering unknown, but many problems that happen during the drilling is credited to this interaction.

The physical-chemical interaction rock/fluids are consequences of both water and ionic species fluxes from and to the rock. The mechanisms of transport in shales, like osmosis, reverse osmosis, diffusion of ions and hydraulic pressure, can cause chemical changes in the shales and fluids, like cation exchange capacity, chemical composition of mud filtrate, the shale matrix and pore fluids, hydration or dehydration of shales (Chenevert, 1969) and swelling pressure (Santos et al, 1996; Santarelli and Carminati, 1995). Also, these mechanisms change the mechanic properties of the fluids, like the weight and viscosity, that are important to stability of well and the retard the fluid invasion in shales (van Oort, 1994; Bol et al., 1996).

This paper is a brief extract of a wider project, currently in development at the Laboratory of Rock-Fluid Interaction of PUC-Rio, and that aims to study the behavior of preserved shale samples when immersed in aqueous solutions. Also, special attention was paid to the fluid properties, which include: electro-chemical, chemical and mechanical properties of the fluid.
To do the immersion tests, two kinds of shales were used, and due to space limitation, the present work presents only the results corresponding to the deionized water.

\section{IMMERSION TEST}

Immersion tests are tests developed to study the shalefluid interaction or shale reactivity. An equipment was developed in which shale samples are put in contact with the fluid and special sensors measure the electro-chemical properties of the fluid throughout the test. This first version of the equipment allows tests with fluids at atmospheric pressure and at down hole temperature condition. Also, at the end of test, a photographic camera was used to monitor the visual qualitative reactions.

The immersion equipment is presented in the figure 1. It is constituted by one round balloon with five entrance ports: four laterals and one central. The central one is used to place the shale pieces inside the balloon and to house the condensator. Three of lateral ports are used to put inside electro-chemical probes and last one is used to collect fluids samples during the tests. The condensator is used to avoid water losses due to vaporization. Besides this, the equipment possesses a heating blanket to keep the temperature constant during the test.

The electro-chemical instrumentation is constituted by a conductimeter/salinometer, a $\mathrm{pH}$ meter and a redox meter. 
Beside this, the probes monitor the solution temperature.

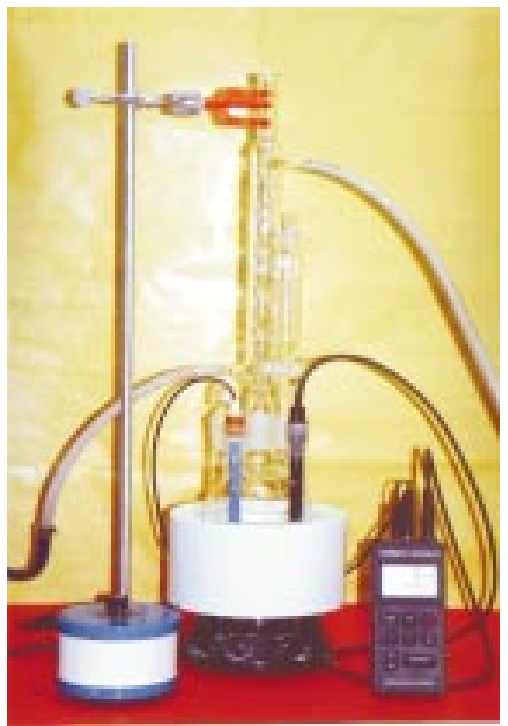

Fig. 1 - Equipment developed for immersion tests.

\section{SHALES AND SOLUTION PROPERTIES}

Two kinds of shales were used: shale originating from Brazilian submarine platform (shale A-B) and shale from onshore sedimentary basin of Venezuela (shale V). Table 1 presents some general characteristics of the tested samples. The specific gravity of grains was determined using the picnometer and the clay fraction was evaluated by sedimentation. The analysis of clay minerals was determined by X-Ray diffraction.

\begin{tabular}{c|c|c}
\hline Shale properties & Shale A-B & Shale V \\
\hline Clay fraction $(\%<2 \mu)$ & 29 & 12 \\
\hline Specific gravity of grains $\left(\mathrm{g} / \mathrm{cm}^{3}\right)$ & 2.69 & 2.71 \\
\hline Clay mineralogy & Kaolinite, illite/smectite and chlorite & Kaolinite and illite/smectite \\
\hline
\end{tabular}

Table 1 - General characteristics of the tested shales.

The results indicate small clay fraction in these shales with low expansibility argilominerals. Table 2 presents the physical properties of shale samples.

The determination of water content was obtained by oven-drying the samples at $105^{\circ}$ for a period of 24 hours. The degree of saturation, voids ratio and porosity values for each sample were obtained with the use of classical soil mechanics expressions (Lambe \& Whitman, 1979).

\begin{tabular}{c|c|c}
\hline Shale properties & Shale A-B & Shale V \\
\hline Water content (\%) & 7.3 & 3.1 \\
\hline Degree of saturation (\%) & 95 & 49 \\
\hline Voids ratio & 0.21 & 0.17 \\
\hline Porosity (\%) & 17.4 & 14.5 \\
\hline
\end{tabular}

Table 2 - Physical properties of shale samples.

These shales present low water content, low porosity and low void ratio. These results are common in shales. The sample from Brazil was almost full saturated, and the Venezuela present low degree of saturation. This is due to the inadequate process of transport and storage, what generated the drying of this shale.
Several aqueous solutions have been tested, but due to space limitation, in the present work only the results corresponding to the deionized water will be presented. Chemical analysis by atomic absorption proved the inexistence of alkaline and earthy alkaline ions in the deionized water. Table 3 presents the properties from deionized water.

\begin{tabular}{c|c|c}
\hline Water properties & Unit & Value \\
\hline $\mathrm{pH}$ at $50^{\circ} \mathrm{C}$ & - & $5.6-6.2$ \\
\hline Redox at $50^{\circ} \mathrm{C}$ & $\mathrm{mV}$ & $230-260$ \\
\hline Electric conductivity at $50^{\circ} \mathrm{C}$ & $\mu \mathrm{S} / \mathrm{cm}$ & $4-5$ \\
\hline Salinity at $50^{\circ} \mathrm{C}$ & $\mathrm{mg} / 1$ & 0 \\
\hline Specific weigh at $20^{\circ} \mathrm{C}$ & $\mathrm{g} / \mathrm{ml}$ & 0.9984 \\
\hline Viscosity at $50^{\circ} \mathrm{C}$ & $\mathrm{mm}^{2} / \mathrm{s}$ & 0.570 \\
\hline
\end{tabular}

Table 3 - Properties from deionized water.

\section{PROCEDURES AND MEASURES}

To do each test, 3 rock fragments were used, with an approximate weight of $70 \mathrm{~g}$. Before the tests, the samples were handled inside a high humidity room, where the cutting of the cores was done with the rock immersed in mineral oil and kept immersed until the beginning of the test, like suggest Santos et al., (1996). This procedure guarantees that the sample is not exposed to air for a long time. Pieces cut from core were used to obtain the original water content from the shale.

Initially, the water was inserted into the balloon and was heated to $50^{\circ} \mathrm{C}$, while this, the probes start to monitor the fluid electro-chemical properties. After this, the shale pieces are inserted into the balloon and the test begins. In these tests, the relationship shale/fluid was kept in 10\%(w/w).

During the test, effluents are collected in a plastic tubes and sent to a chemistry laboratory to quantify the cations and anions present in water. At the end of the immersion test, the effluents are collected to make chemical and physical analysis. The physical analysis included viscosity and specific density.

\section{ELECTRO-CHEMICAL RESULTS}

The fluids electro-chemical properties determine the behavior of ions during the immersion tests. The $\mathrm{pH}$ value is an indicator of the acidification or alkalization of a solution and the Redox is an indicator of degree of reduction or oxidation. The electric conductivity and salinity quantify, respectively, the amount of free ions and the salts present in the solution. These properties were used to understand the movements into or out of fluid in contact with shale A-B and V, during the tests. Figures 2, 3, 4 and 5 present, respectively, the results of $\mathrm{pH}$, Redox, electric conductivity and salinity.

The initial values correspond to the deionized water. The $\mathrm{pH}$ results indicated that the solutions become strongly alkaline. At the same time, the Redox values indicate that the solutions have become minus reduced. Electric conductivity of fluids indicate that the ions migrated from the shale samples to the fluid, that caused in the case of shale A-B, a increase in the salinity of the fluid. 


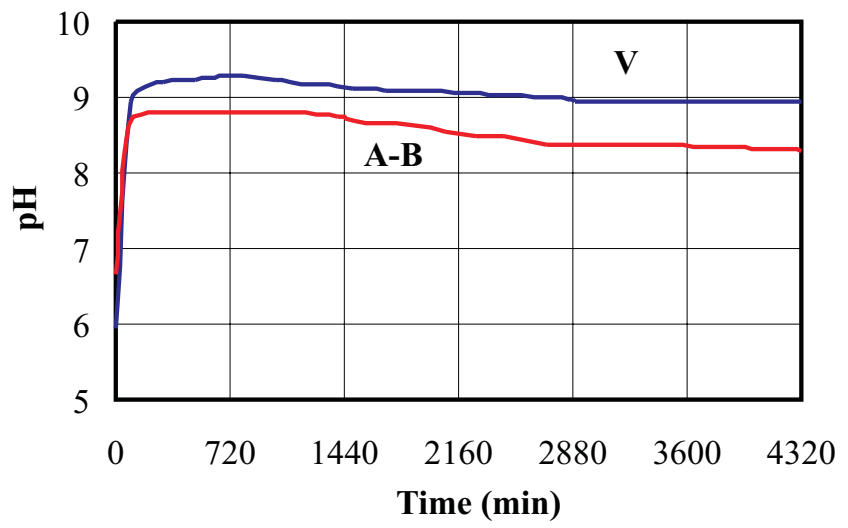

Fig. 2 - pH during the immersion tests.

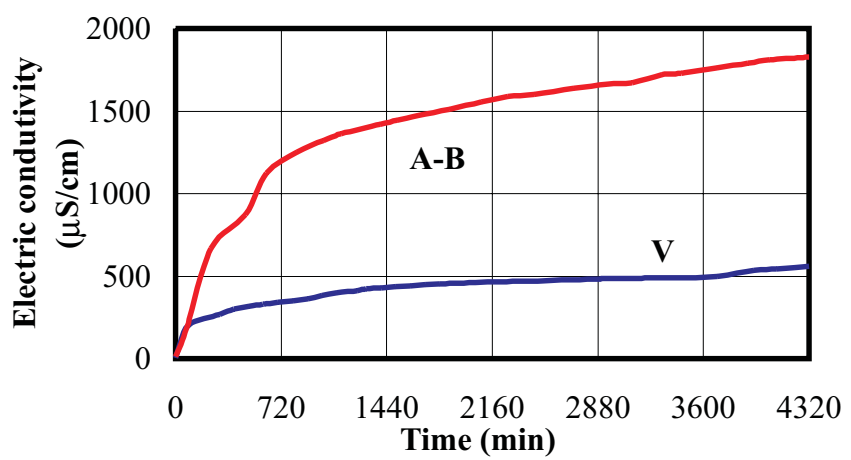

Fig. 4 - Electric conductivity during the immersion tests.

The results indicate that during the first day of test it occurs the biggest changes in the $\mathrm{pH}$, Redox, electric conductivity and salinity, and that suggests that the shalefluid interaction occurs more strongly during this period. After this, the curves tend to become horizontal.

\section{CHEMICAL ANALYSIS}

Chemical analysis was performed at the Atomic Emission Spectrometry Laboratory (cations) and Ionic Chromatography Laboratory (anions) at PUC-Rio, on the deionized water samples. In this paper, will just present the following components: $\mathrm{Na}^{+}$, $\mathrm{Si}^{++}, \mathrm{Ca}^{++}, \mathrm{K}^{+}, \mathrm{Cl}^{-}$and $\mathrm{SO}_{-2}^{4}$, since they were the ions that migrated from the samples to the fluids. Other elements $\left(\mathrm{Mg}^{++}\right.$, $\mathrm{Al}^{++}, \mathrm{Ba}^{++}, \mathrm{Sr}^{++}$and $\mathrm{Fe}^{++}$) migrated less than $1 \mathrm{mg} / \mathrm{l}$. The variation of $\mathrm{Na}^{+}, \mathrm{Si}^{++}, \mathrm{Ca}^{++}, \mathrm{K}^{+}, \mathrm{Cl}^{-}$and $\mathrm{SO}_{-2}{ }^{4}$ concentrations on water during the immersion tests are presented, respectively, in the figures $6,7,8,9,10$ and 11.

The results show that ions migrated from the shale cores to the water fluid by chemical diffusion. These elements exit the rock matrix and go to the fluid, under a chemical gradient.

\section{VARIATIONS IN FLUID DENSITY AND VISCOSITY}

After the immersion tests, the effluent was collected to quantify the variation on the physical property of the immersion fluid. The viscosity was performed at the Termo-Science

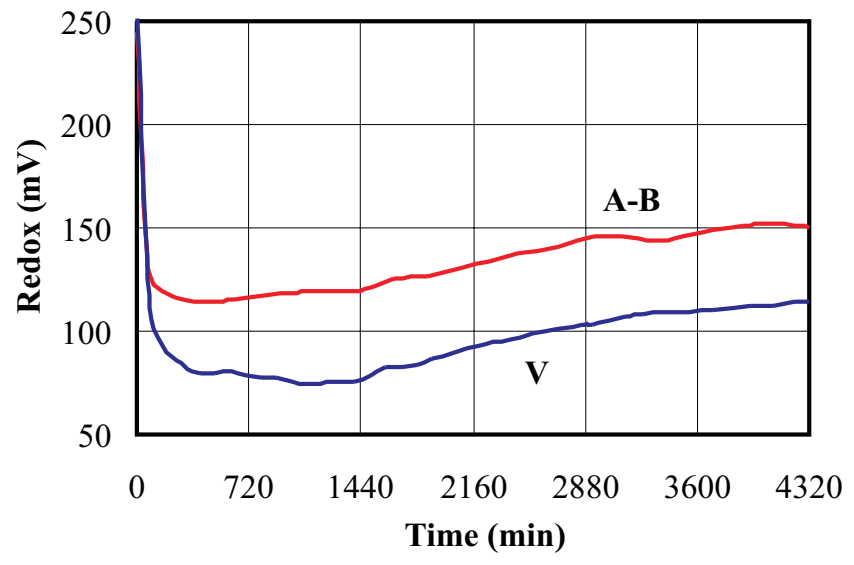

Fig. 3 - Redox during the immersion tests.

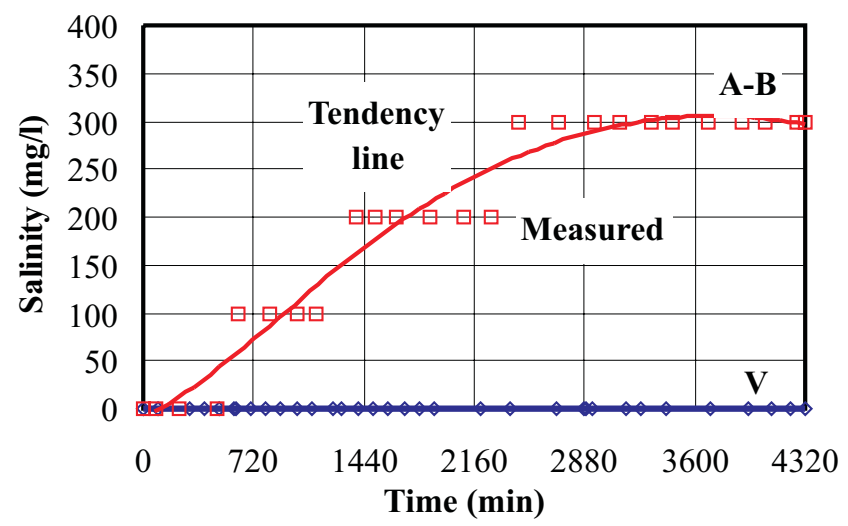

Fig. 5 - Salinity during the immersion tests.

Laboratory of the Catholic University of Rio de Janeiro (PUCRio). For the accomplishment of the test, the viscosimeter was immersed in a bath full of glycerin that maintained the temperature at $50^{\circ} \mathrm{C}$.

The density of water was performed in the volumetric pipette $(10 \mathrm{ml})$ and the weight was controlled in an electronic balance $(0,0001 \mathrm{~g})$. Table 4 shows the variations in viscosity and density of the fluid caused by the interaction shale-fluid after 3 days of immersion test.

\begin{tabular}{c|c|c|c|c}
\hline Water proprieties & Shale & Initial value & Final value & Variation (\%) \\
\hline \multirow{2}{*}{$\begin{array}{c}\text { Density } \\
(\mathrm{g} / \mathrm{ml})\end{array}$} & A-B & 0.9984 & 0.9995 & 0.1101 \\
\cline { 2 - 5 } & V & 0.9984 & 0.9987 & 0.0300 \\
\hline \multirow{2}{*}{ Viscosity $\left(\mathrm{mm}^{2} / \mathrm{s}\right)$} & A-B & 0.5708 & 0.5726 & 0.3153 \\
\cline { 2 - 5 } & V & 0.5708 & 0.5737 & 0.5080 \\
\hline
\end{tabular}

Table 4 - Variations on the physical water properties caused by 3 days of immersion .

The results indicate that the interaction rock-fluid generated small increases in the density and the viscosity of the fluids. This increase in density was due by migration of ions from the rock to the fluid. As the migration was more intense in the Brazilian shale, proven by the high variation on the electric conductivity and in chemical analysis, this shale generated more elevation on the fluid density.

The fluid in contact with shale $\mathrm{V}$ presented a large increase in its viscosity. This can be attributed to the high dissolution of the carbonates calcium $\left(\mathrm{Ca}^{++}\right)$present in the shale, since the calcium has elevated viscosity. 


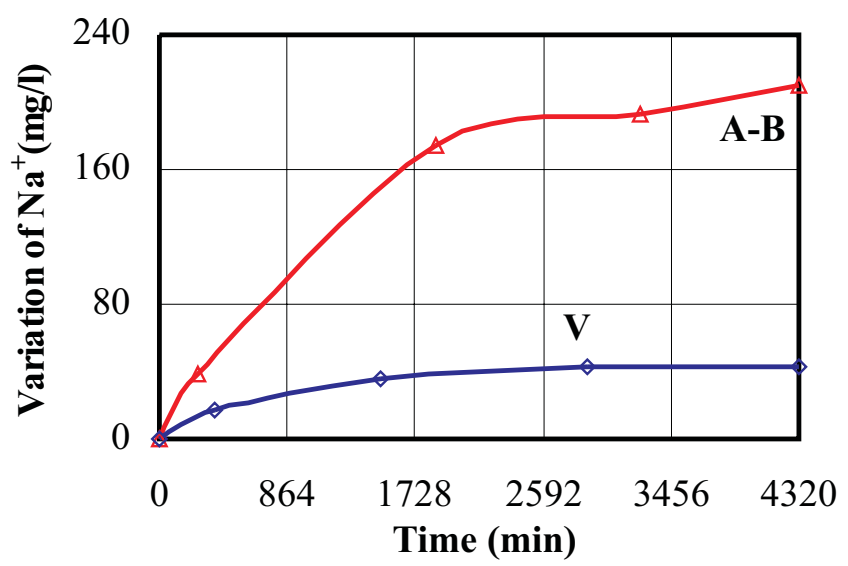

Fig. 6 - Variation of $\mathrm{Na}^{+}$concentrations on the water fluid during the immersion tests.

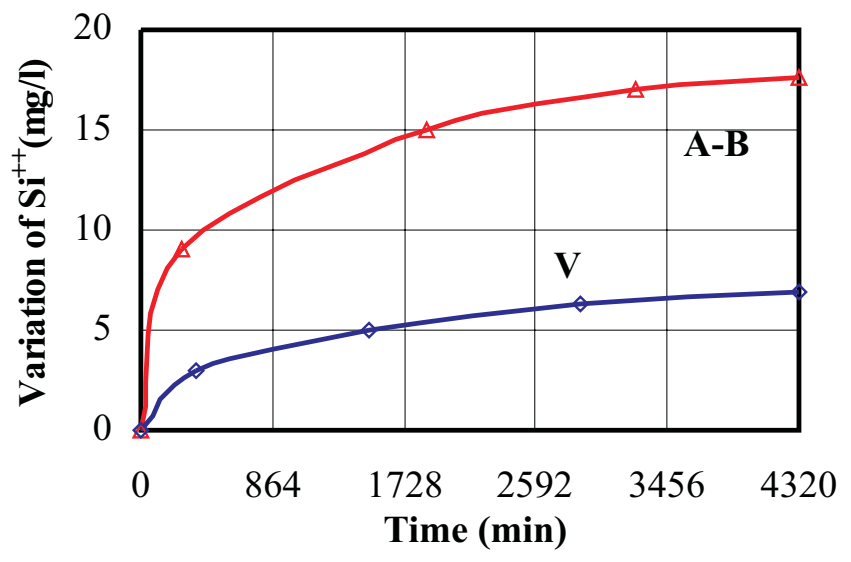

Fig. 8 - Variation of $\mathrm{Si}^{++}$on the deionized water during the immersion tests.

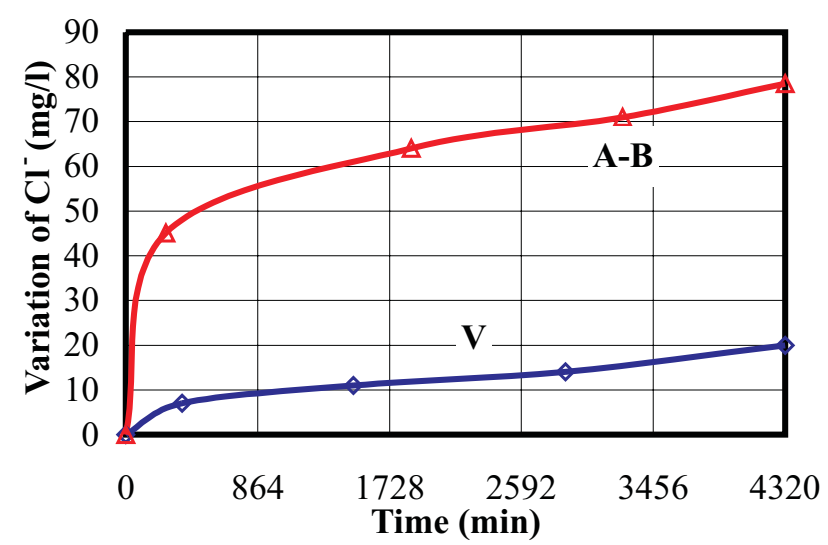

Fig. 10 - Variation of $\mathrm{Cl}^{-}$on the deionized water during the immersion tests.

\section{WATER CONTENT OF SHALES SAMPLES}

The water content of the shale samples was obtained by oven drying at $105{ }^{\circ} \mathrm{C}$ for 24 hours as recommended by the International Society of Rock Mechanics, like was described before. The same methodology was used at the end of immersion test, when one core was used to obtain the final free water.

These results show that shales in contact with a deionized water solution suffer hydration. Is can be cause by an initial non-saturation of shale samples and by the osmosis

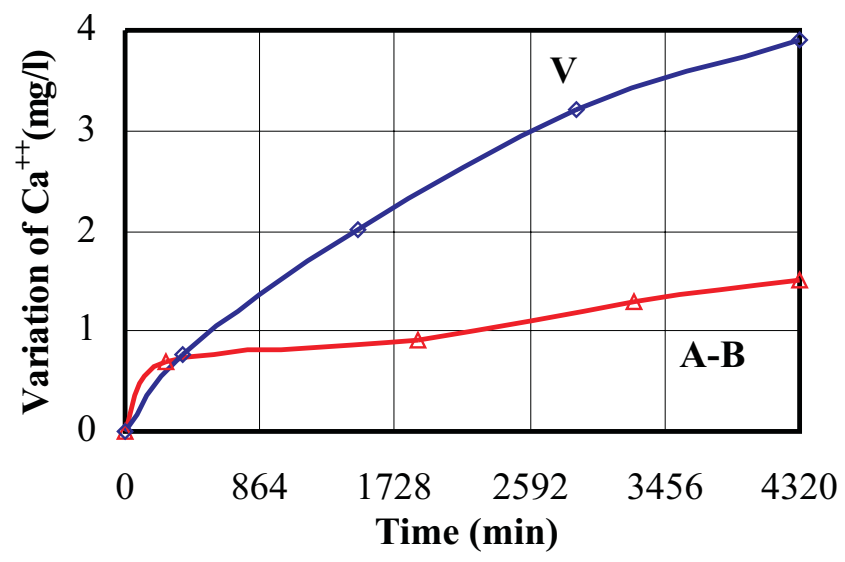

Fig. 7 - Variation of $\mathrm{Ca}^{++}$concentrations on the water fluid during the immersion tests.

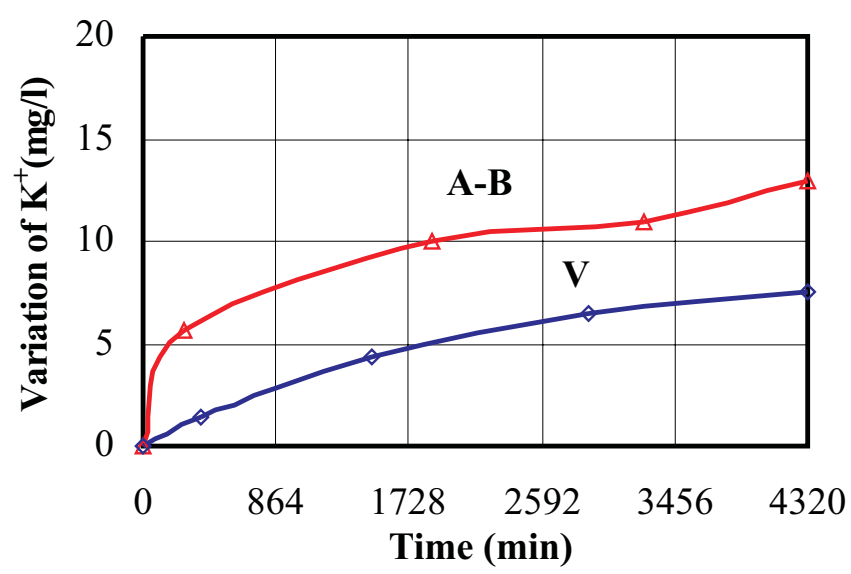

Fig. 9 - Variation of $\mathrm{K}^{+}$on the deionized water during the immersion tests.

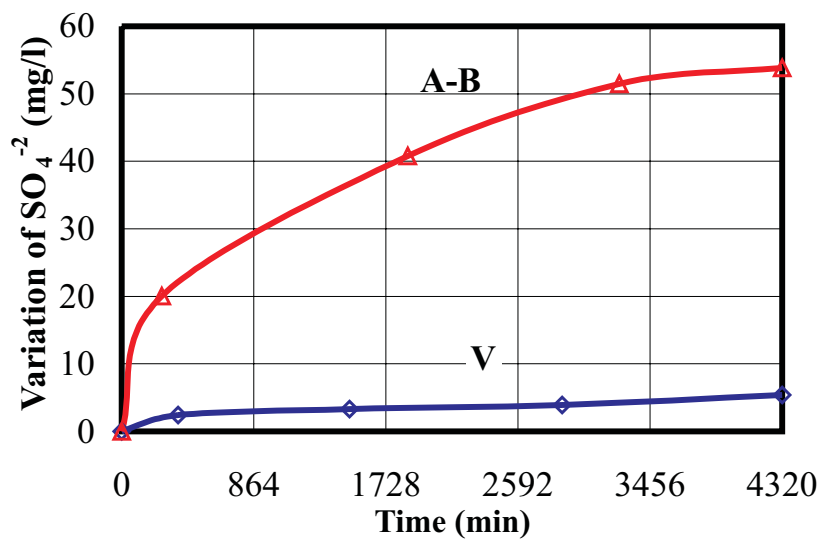

Fig. 11 - Variation of $\mathrm{SO}_{4}^{-2}$ on the deionized water during the immersion tests.

process. The Venezuela shale shows a high hydration process that can be explained by it low initial saturation value. The results of variations of free water are present in the table 5.

\begin{tabular}{c|c|c|c|c}
\hline Shale property & Shale & Original value & 3 days & Variation (\%) \\
\hline \multirow{2}{*}{ Water content (\%) } & A-B & 7.29 & 11.03 & 51.30 \\
\cline { 2 - 5 } & V & 3.09 & 5.04 & 63.11 \\
\hline
\end{tabular}

Table 5 - Water content for the shale samples immersed in deionized water during 3 days. 


\section{QUALITATIVE REACTIONS OF SHALE SAMPLES}

A photographic camera was used to take pictures of shale samples after the immersion tests, monitoring qualitative reactions. At the end of immersion test, the samples and the fluids are put in a Becker $(500 \mathrm{ml})$ to see better the cores and the solutions.

The figure 12 shows the shales immersed in the water after the test. The photos shows that the fluid used in contact with shale A-B fluid became cloudy and dark, caused by the high quantities of solid dispersed in it. This effect was not observed in the fluid used with shale V. It can be explained by the strong cementation that precluded particle dispersion. Figure 13 illustrates the presence of fractures generated during the shale sample hydration.

\section{SOLID DISPERSION}

The dispersed solids are presented in the table 6. The material considered dispersed in the fluid are all the solids originating from the fragmented shales. The percentage of dispersed material in the solutions $(\mathrm{D} \%)$ was calculated by the following ways, where $\mathrm{W}_{\text {st }}$ is the dry weight of the sample before the immersion, obtained by physical properties and $\mathrm{W}_{\mathrm{sd}}$ is the dry weight of the dispersed material after immersion tests. $\mathrm{W}_{\mathrm{sd}}$ was obtained by oven-drying the dispersed material at $105^{\circ}$ for a period of 24 hours.

$$
D(\%)=W_{s d} / W_{s t} x(100)
$$

\begin{tabular}{c|c} 
Shale & Dispersed solids (\%) \\
\hline A-B & 5.86 \\
\hline V & 1.32
\end{tabular}

Table 6 - Quantification of dispersed solids in the solutions.

The results show that the dispersed solids in the fluids were no negligeable. The dispersion is a function of changes in structure of rock matrix and in the bound and crystalline water, caused by the hydration of the cores.

\section{CATION EXCHANGE CAPACITY}

Table 7 presents the results obtained for shales using a methylene blue test (Higgs, 1988), with concentration of $1 \mathrm{~g} / \mathrm{l}$ and control onto the $\mathrm{pH}$ value, keeping the solution neutral. The tests were carried out using $1 \mathrm{~g}$ from the coarse and clay fraction of the shales. Also, in the same table are presented the results obtained by the ammonium acetate method. In this test, 4 $\mathrm{g}$ were used from coarse fraction of the shale samples. This test allows the evaluation of the individual cations that are being interchanged. The Brazilian shale has a high CEC value, and the main interchangeable cation is $\mathrm{Na}^{+}$which suggests the presence of sodic smectite.

The sample from Venezuelan shale presented small CEC values both in MBT method and in the ammonium acetate test. This shale showed a large amount of interchangeable cation is $\mathrm{Ca}^{++}$, which gives, to this shale, a low reactivity profile.

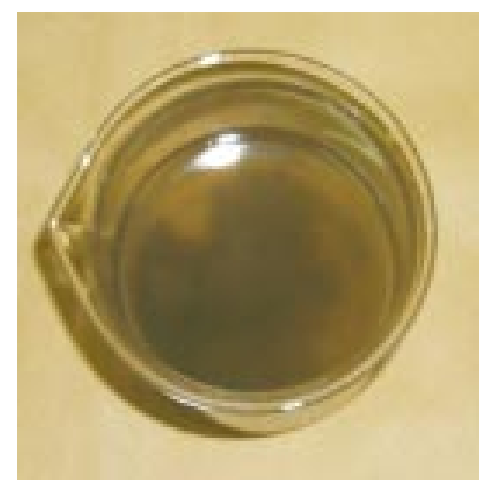

Shale A-B

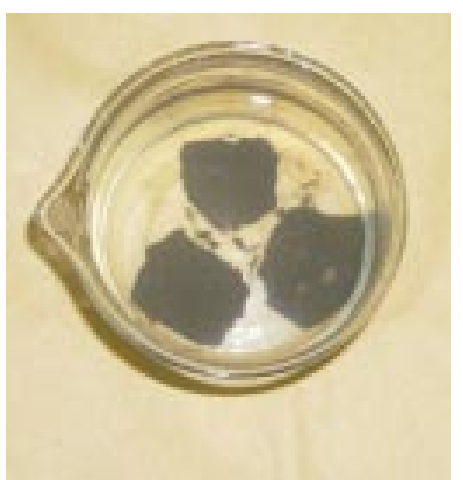

Shale V

Figure 12 - Shale samples after immersion in water for 3 days. Dispersed solids and superficial disintegration.

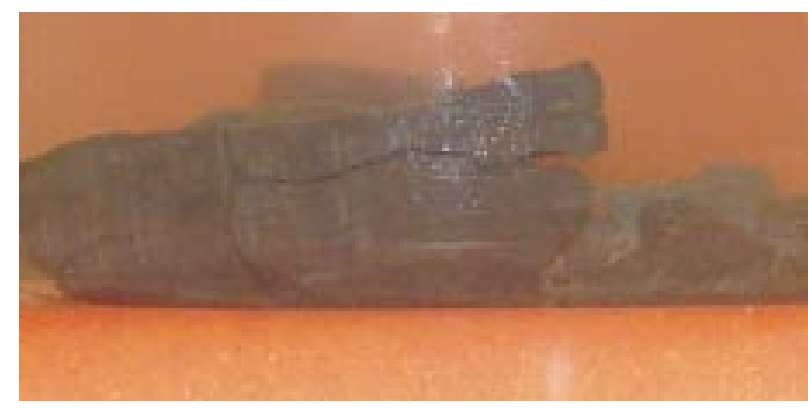

Shale A-B

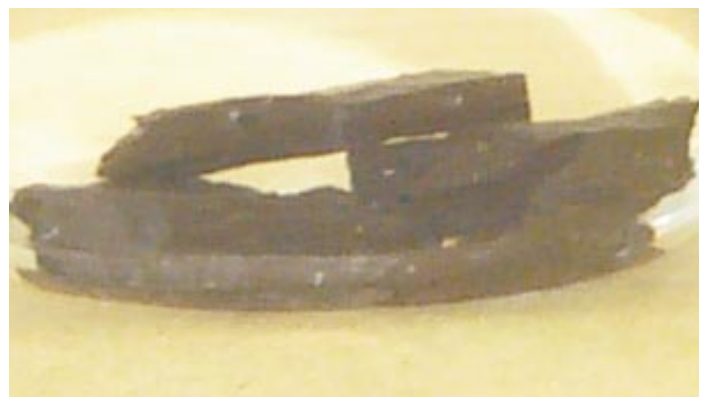

Shale V

Figure 13 - Shale samples after immersion in water for 3 days. Creation of fractures in the shale cores. 
Displayed in Table 7, the results indicate a small reduction of interchangeable cations and the $\mathrm{Na}^{+}$was the more reduced in all the shales. We can conclude that, under the test conditions, the immersion fluid did not cause changes in the structure of clay minerals during the immersion tests.

\begin{tabular}{|c|c|c|c|c|c|c|c|c|c|}
\hline \multirow{3}{*}{ Shale } & \multicolumn{2}{|c|}{$\begin{array}{c}\text { MBT - CTC } \\
(\mathrm{meq} / \mathbf{1 0 0 g})\end{array}$} & \multicolumn{7}{|c|}{ Ammonium Acetate - coarse fraction (meq/100g) } \\
\hline & \multirow{2}{*}{$\begin{array}{l}\text { Coarse } \\
\text { fraction }\end{array}$} & \multirow{2}{*}{$\begin{array}{c}\text { Clay } \\
\text { fraction }\end{array}$} & \multirow{2}{*}{ CTC } & \multicolumn{6}{|c|}{ Interchangeable cations } \\
\hline & & & & $\mathrm{Na}^{+}$ & $\mathbf{K}^{+}$ & $\mathrm{Ca}^{++}$ & $\mathrm{Mg}^{++}$ & $\mathrm{Sr}^{++}$ & $\mathrm{Ba}^{+}$ \\
\hline A-B Natural & 24.5 & 27.0 & 29.10 & 14.8 & 2.9 & 8.7 & 2.0 & 0.63 & 0.07 \\
\hline A-B $\mathbf{H}_{2} \mathbf{O}$ & 24.0 & 25.8 & 26.90 & 13.2 & 2.7 & 8.4 & 1.9 & 0.63 & 0.07 \\
\hline V Natural & 11.4 & 12.0 & 16.50 & 1.52 & 1.95 & 12.13 & 0.77 & 0.07 & 0.06 \\
\hline $\mathrm{V} \mathrm{H}_{2} \mathrm{O}$ & 10.6 & 11.5 & 16.00 & 1.09 & 1.90 & 12.12 & 0.76 & 0.07 & 0.06 \\
\hline
\end{tabular}

Table 7 - Cation Exchange Capacity and Interchangeable cations.

\section{CHEMICAL ANALYSIS OF TESTED SHALES}

The chemical analyses were carried out at the Chemistry Division of Lakefield Geosol Laboratory by x-ray fluorescence. The chemical composition of shales from Brazil is rich in the following oxides: $\mathrm{SiO}_{2}, \mathrm{Al}_{2} \mathrm{O}_{3}, \mathrm{CaO}$ and loss on fire and the shale from Venezuela proved to be rich in $\mathrm{SiO}_{2}, \mathrm{Al}_{2} \mathrm{O}_{3}$ and loss on fire. The amount of loss on fire was determined to quantify the presence of $\mathrm{H}_{2} \mathrm{O}, \mathrm{S}$ and $\mathrm{CO}_{2}$ in the rock matrix (Table 8).

Comparing the values displayed in the table, it can be observed that the samples from Brazil and Venezuela after 3 days of immersion in deionized water suffered a small percentage reduction of oxides (minus than 1\%), that indicate that the structure of shales samples suffered small chemical alteration. The increase of loss on fire results of shale A-B (3.38\%) was larger than shale $\mathrm{V}(1.02 \%)$. These results indicate that the crystalline water had increase.

\begin{tabular}{c|c|c|c|c}
\hline \multirow{2}{*}{$\begin{array}{c}\text { Oxides } \\
(\mathbf{\%})\end{array}$} & \multicolumn{2}{|c|}{ Shale A-B } & \multicolumn{2}{c}{ Shale V } \\
\cline { 2 - 5 } & Natural & After 3 days & Natural & After 3 days \\
\hline $\mathbf{S i O}_{\mathbf{2}}$ & 40.5 & 39.9 & 51.2 & 51.0 \\
\hline $\mathbf{A l}_{\mathbf{2}} \mathbf{O}_{3}$ & 13.0 & 12.3 & 20.7 & 20.1 \\
\hline $\mathbf{C a O}$ & 18.1 & 17.7 & 3.7 & 3.6 \\
\hline $\mathbf{L o s s} \mathbf{O n}$ fire & 15.43 & 18.81 & 11.04 & 12.16 \\
\hline $\mathbf{F e}_{2} \mathbf{O}_{3}$ & 5.8 & 5.5 & 6.8 & 6.7 \\
\hline $\mathbf{K}_{\mathbf{2}} \mathbf{O}$ & 2.5 & 2.3 & 2.3 & 2.2 \\
\hline $\mathbf{M g O}$ & 1.4 & 1.1 & 3.1 & 3.0 \\
\hline $\mathbf{N a}_{\mathbf{2}} \mathbf{O}$ & 2.1 & 1.3 & 0.33 & 0.27 \\
\hline $\mathbf{T i O}_{\mathbf{2}}$ & 0.80 & 0.73 & 0.72 & 0.69 \\
\hline $\mathbf{P}_{\mathbf{2}} \mathbf{O}_{\mathbf{5}}$ & 0.32 & 0.31 & 0.15 & 0.15 \\
\hline $\mathbf{M n O}$ & 0.02 & 0.02 & 0.10 & 0.09 \\
\hline $\mathbf{B a O}$ & 0.0269 & 0.0243 & 0.0433 & 0.0429 \\
\hline
\end{tabular}

Table 8 - Chemical analysis of shale samples before and after 3 days of immersion test.

\section{CHEMICAL ANALYSIS OF THE PORE FLUID}

Table 9 present the results of pore fluid composition for shales from Brazil and Venezuela, before and after the immersion tests. The method used to extract the pore fluid is described by Schmidt (1973), where the sample was dried and the salts removed by washing. The effluent is used to measure the salt content. These tests are importants to understand the behavior of solubility of salts present in the pore fluid during the immersion tests.

The results indicate that the Brazilian shale has more cations and anions in its pore fluid than the Shale from Venezuela. This can be explained by the origin of the shales.
The shale A-B is a rock originated from Brazilian submarine platform and the shale $\mathrm{V}$ came from an onshore sedimentary basin of Venezuela. The results also indicate that after immersions tests, the ions migrated by diffusion from the shale pore fluid to the immersion fluid. This was suggested by the chemical analysis of water.

\begin{tabular}{l|c|c|c|c}
\hline \multirow{2}{*}{$\begin{array}{c}\text { Ions } \\
(\mathbf{m g} / \mathbf{l})\end{array}$} & \multicolumn{2}{|c|}{ Shale A-B } & \multicolumn{2}{c}{ Shale V } \\
\cline { 2 - 5 } & Natural & After 3 days & Natural & After 3 days \\
\hline $\mathrm{Na}^{+}$ & 14,385 & 14,298 & 87 & 83 \\
\hline $\mathrm{K}^{+}$ & 354 & 350 & 21 & 19 \\
\hline $\mathrm{Ca}^{++}$ & 875 & 873 & 32 & 29 \\
\hline $\mathrm{Mg}^{++}$ & 131 & 129 & 46 & 42 \\
\hline $\mathrm{Cl}^{-}$ & 12,769 & 12,707 & 74 & 70 \\
\hline $\mathrm{SO}_{\overline{4}}{ }^{2}$ & 9,354 & 9,301 & 66 & 64 \\
\hline
\end{tabular}

Table 9 - Variations of pore fluid composition for shales from Brazil and Venezuela, before and after the immersions tests.

\section{CONCLUSIONS}

A very simple immersion test is being proposed to study the shale-fluid interaction, where the equipment is able to simulate the temperature "in situ" condition. In the present work, special attention was given to the immersion fluid, by measuring its electro-chemical, mechanics and chemical properties.

The electro-chemical results indicate a strong alkalization and the fluid became less reduced, due to the presence of sulfates and oxides in the fluid. The electric conductivity indicated the direction of movement and behavior of the ions. The results indicated that the ions migrated from the shale samples to the fluid, and that created an increase in the salinity, that was noticed during the test carried out with the shale A-B.

The results of chemical analysis indicated that the ions present on the fluids came from, mainly, the pore fluid, but the rock matrix suffered a reduction. It was caused by non-ideal semi-permeable membrane (deionized/shale interface) that, by chemical diffusion, prevents the transfer of ionic and molecular from the shale to the fluid.

The increase in the water content indicate that the rock suffered hydration and that may have caused an increase in pore pressure. The transfer of water to the shales samples can be attributed to chemical osmosis and the non-saturation of shale samples. The alteration in shale structure can be monitored too, by the reduction of CEC, caused by the lost of interchangeable cations. The destabilization of shale structure could be observed by creation of fractures, superficial disintegration and by dispersed solids in the fluid.

The physicals properties of fluids indicate small variations. The density became higher as well as the viscosity of the fluids. This increase was caused by the high of ions and molecules presents on the water. Some of these elements have higher viscosity than the water, like the chlorides and sulfates.

\section{ACKNOWLEDGMENTS}

The authors wish to thank ANP and CNPq for the scholarship support. Special thanks go to Dr. Rosana Lomba by your suggestions and Petrobras for proving the cores used in this work. This work is dedicated to the Israel's God, for his infinite love. 


\section{REFERENCES}

1. Bol, G. M.; Wong, S. W.; Davidson, C. J.; Woodland, D. C. (1994), "Borehole stability in shales", Society of Petroleum Engineers Journal, paper 24975, 1992. European Petroleum Conference, Cannes, Nov., pp. 16-18.

2. Chenevert, M. E. (1969), "Shale hydration mechanics", Society of Petroleum Engineers Journal, paper 2401.

3. Higgs, N. B. "Methylene Blue Adsorption as a rapid and Economical Method of Detecting Smectite", Geotechnical Testing Journal, Vol.11, No 1, May, 1988, pp. 68-71.

4. Lambe, T. W. and Whitman, R. V. (1979), "Soil Mechanics", New York, John Wiley and Sons, 1970.

5. Santarelli, F.J. and Carminati, S., " Do shales swell? A critical review of available evidence". SPE/IADC 29421, 1995, IADC/SPE Drilling Conference, pp. 741-756.

6. Santos, H. M. R., Diek, A., Roegiers, J. C. and da Fontoura, S. A. B., "Investigation of the effects of sample handling procedures on shale properties", Proceedings of the $2^{\text {nd }}$ North American Rock Mechanics Symposium, Montreal, June, 1996, vol. 1, pp. 951-958

7. Santos, H. M. R., Diek, A., Roegiers, J.C. and da Fontoura, S.A.B.: "Can shale sweeling be (easly) controlled?," Eurock'96, Barla (ed.), pp. 99-106, 1996, Balkema, Rotterdam.

8. Schmidt, G. W. (1973), "Interstitial water composition and geochemistry of deep Gulf Coast Shales and Sandstone", The American Association of Petroleum Geologists Bulletin, Tulsa, UK, vol. 57(2), pp. 321-337.

9. Van Oort, E., "A novel technique for the investigation of drilling fluid induced borehole instability in shales", Society of Petroleum Engineers Journal, paper 28064, 1994, Conference on Rock Mechanics in Petroleum Engineering, Delft, Aug., pp. 29-31.

10. Van Oort, E., "Physico-chemical stabilization of shales", Society of Petroleum Engineers Journal, paper 37263, SPE International Symposium on Oilfield Chemistry, 1997, Houston, Feb., pp. 523538 